\title{
Analysis of Informal Urban Settlement Upgrading: The Case of Ng'ombe Slum Upgrading in Zambia
}

\author{
Jonathan Simbeya Mwamba, Zhenwei Peng \\ College of Architecture and Urban Planning, Tongji University, Shanghai, China \\ Email: jsmarchitect@gmail.com
}

How to cite this paper: Mwamba, J. S., \& Peng, Z. W. (2020). Analysis of Informal Urban Settlement Upgrading: The Case of Ng'ombe Slum Upgrading in Zambia. Current Urban Studies, 8, 509-532. https://doi.org/10.4236/cus.2020.84028

Received: October 28, 2020

Accepted: November 29, 2020

Published: December 2, 2020

Copyright $\odot 2020$ by author(s) and Scientific Research Publishing Inc. This work is licensed under the Creative Commons Attribution International License (CC BY 4.0).

http://creativecommons.org/licenses/by/4.0/

\section{(c) (i) Open Access}

\begin{abstract}
Informal settlements constitute a major part of the urban landscape of most cities in Zambia. There have been myriad of development interventions undertaken to manage the informal settlement challenge in the country, with city administrators reviewing the approach to informal urban settlement upgrading in an attempt to control them. Developing regularisation strategies is complicated by the complex dynamics which are specific to individual informal urban settlements. In order to effectively counter this challenge, it is important to draw lessons from past regularisation interventions. The paper studies the recurring themes and common elements in contemporary settlement regularisation programmes from literature which form the conceptual framework for this study. These themes are studied to ascertain their relevance for future development interventions in informal settlements. Ng'ombe slum upgrading project in Lusaka, Zambia, is used as a case study to ascertain how these elements performed and assess their potential for replication in similar settings. The study recommends stakeholders incorporate common effective participatory informal settlement upgrading elements in future interventions to guarantee more equity and sustainability of upgrading initiatives.
\end{abstract}

\section{Keywords}

Informal Urban Settlements, Settlement Regularisation, Upgrading Elements, Stakeholders, Lusaka

\section{Introduction}

A principle challenge facing Sub-Saharan African cities is the proliferation of informal settlements. Nearly three-quarters of Africa's urban residents subsist in 
informal settlements obscured from any state or local government support (Cities Alliance, 2006). Slums or informal settlements are quickly becoming the most visible expression of urban poverty in cities of the developing world. Constituting a variety of tenement housing, poor tenure arrangements and limited access to basic services and infrastructure, such settlements are referred to by a wide range of names (UN-Habitat, 2003). Contrary to wide held notions, most dwellers live in informal settlements by choice, as these localities offer the advantage of belonging to a population that is out of sight of legality away from the rules and regulations of mainstream society. To a large section of the urban population, informal settlements present the most accessible and affordable living option for the urban poor. Cronin (2012) also observes that informal settlements are often only affordable living option for poor migrants moving to the cities. As a measure to improve informal settlement conditions many states have adopted varied measures in regularising informal urban communities. Unfortunately these interventions often fail to meet the competing needs of informal urban settlement residents as interventions do not adequately address the realities of urban life.

The conceptual frame work of this research will review selected common characteristics that run through informal urban settlement regularisation initiatives. These characteristics will guide the case study assessment of informal settlement upgrading in Zambia. This article reviews a participatory settlement upgrading project in Lusaka, Zambia as a model and identifies elements of special interest that can be replicated for future upgrading initiatives. The term "upgrading" emphasizes the intent to improve living standards of the urban poor and reveals the challenges that need attention in such projects (Werlin, 1999). Ng'ombe participatory slum upgrading illustrates experiences and lessons which are vital for future upgrading initiatives with similar settings.

\section{Literature Review}

\subsection{Informal Settlements or Slums}

The word "Slum" first appeared in 1812 and was used to describe the overcrowded, squalid inner-city tenements where working class housing was built during the British industrial revolution (Singh, 2014; Gilbert, 2007). In developing countries, the word simply refers to lower-quality or informal housing. UN Habitat defines slums as overcrowded areas lacking safe water, sanitation, quality housing and tenure security (UN-Habitat, 2003). Huchzermeyer (2011) notes that identifying all poor settlement types in the category of slums ignores the individual settlement traits and possibilities for improvement and depicts them as falling beyond set standards.

Globally close to 860 million urban dwellers lived in slum conditions by 2012 . Sub-Saharan Africa (SSA) has one of the highest proportions of urban population living in slums at $72 \%$ which constitutes $25 \%$ of slum population in the de- 
veloping world (UN-Habitat, 2014). Rapid urban growth without needed urban infrastructure development has resulted in a high proportion of informal settlements (UN-Habitat, 2008). The terms slum and informal settlement are often used interchangeably in literature and are similarly employed in this paper. Informal settlement in this instance is used to refer to poor quality housing in low-income communities, as well as the absence of infrastructure in such communities. Its use in no way refers to the character and actions of people living in these communities (Singh, 2014). Informal settlements are known by a variety of names across the globe and are commonly referred to as "komboni" in Zambia.

\subsection{Informal Settlement Upgrading}

According to Cities Alliance (2006), informal settlement upgrading is a process which involves the improving, formalising and incorporating of informal settlements by providing residents with the lacking land rights, public infrastructure and services legally and constitutionally entitled to them (Du Plessis, 2017). Over the past 6 decades various interventions have been undertaken globally. (Mukhija, 2002) notes that some previous urban upgrading projects have failed because of centralized state planning and top-down execution. State interventions tended to tended to often be counter-productive and not in the best interest of the poor beneficiaries. The state actually made it difficult to replicate successful pilot projects. Werlin (1999) observes that early John F.C. Turner was the first to acknowledge government's shortcomings in slum upgrading. He argued for governments to cease building and managing housing. He advocated for the users (local communities) to be the principal actors in the upgrading process. Critics argue that his policies assumed that the absence of State intervention would lead to more autonomy for low-income groups and that his ideas offered no clarity on how to implement and institutionally support upgrading. Many in formal settlement upgrading proponents encourage states to institute programmes that address the root cause and not just the outcome of the slum problem. This advocates for in situ upgrading of slum conditions as opposed to slum relocation. As earlier suggested Turner, when provided with the right incentives such as secure tenure and access to credit, slum dwellers have the potential to gradually improve their homes and living environments (Werlin, 1999). Slum upgrading was touted as a development strategy that can be executed without active state involvement but requiring a people centred strategy where individuals and communities efficiently control the upgrading outcomes.

Gilbert (2007) however observes that the dynamism and variety in informal settlements complicates the formulation of an absolute solution to the diverse slum challenges. Likewise, the interplay between different actors in regularisation is another cause for concern, since stakeholders have their own motivations and objectives. This can often lead to delicate partnerships upon which the success of intervention lies (Danso-Wiredu \& Midheme, 2017). Du Plessis (2017) notes that partnerships between stakeholders are essential for achieving the de- 
sired upgrading objectives. Where local communities feel sidelined or stakeholders fail to deliver on their objectives, projects may have to be scaled down, abandoned or renegotiated altogether. There however, is widespread agreement on what constitutes successful slum upgrading. Existing United Nation informal settlement upgrading guidelines favour participatory bottom-up approaches, where residents drive the upgrading initiatives with the guidance of state and no-state actors. Providing secure and legal tenure to informal settlement residents is important in ensuring the viability of upgrading initiatives, which if not well managed may lead to gentrification of communities, high rentals and displacement of the original residents. Key elements which appear in successful slum upgrading programs have been reviewed in this article and form the conceptual framework of analysis in this article.

\subsection{Elements That Characterise Informal Settlement Upgrading}

\section{1) Land Tenure Relations}

Makasa (2010) defines land tenure as the right of a tenant to hold on to land and enjoying all privileges that come with it. It relates to the terms and conditions on which land is held, used and transacted. Secure tenure thus is at the crux of informal settlement upgrading. In most Third World countries, the single major obstacle to the development of housing for the urban poor is land ownership. The lack of tenure security for the urban poor and their neighbourhoods leads to uncertain livelihood opportunities. Slum dwellers seldom own the houses or the land on which they live but often rent houses or rooms from landowners without the approval of local authorities (Werlin, 1999). People at risk of eviction do not invest in housing unless they have a sense of permanence and the security that any investment in housing can be recouped. Furthermore illegality and informality in informal settlements make them susceptible to exploitation, corruption and extortion. Uncertainties in the ownership of land in informal settlements are often a recipe for conflict and a barrier to state sanctioned tenure security (Werlin, 1999).

The UN-Habitat (2012) explains that the strategic value of the state authorities providing occupancy rights to slum residents lies in the facts that it offers them more awareness on their "rights to the city" and effective protection against forced evictions. Occupancy rights are a tool for social mobility, enabling residents to establish organisations that transcend ethnic, religious, gender and geographical boundaries. Secure tenure can stimulate investment of own resources for the purpose of improving shelter and services and can be used as a tool for making claims or negotiating for community resources and basic services from state authorities. Furthermore, it serves as an avenue for legitimizing land or structures on that land as forms of guarantee for credit and investment (Krajisnik, 2011). Legalisation of informal settlements has however been widely implemented in the global south. There have been varied responses to legalisation based on the local context, the types of informal settlement, prevailing govern- 
ment policy and civil society advocacy on behalf of the slum communities. Tenure legalisation encourages the integration of informal land and housing markets within the formal economy. This is by facilitating the access to land ownership through property titles. Durand-Lasserve \& Clerc (1996) notes that beyond offering land ownership and titling programs, current tenure security policies also provide social and economic integration of informal settlements. A recent feature of upgrading in Zambia is that tenure security of informal settlement dwellers is given recognition. Informal settlements have to be legalised and officially declared an improvement area in order to be considered for state upgrading and dwellers are able to secure a 30-year occupancy right. There is a relatively high level of ownership in improvement areas and 30 out of 37 informal settlements around Lusaka have already been legalised.

\section{2) Partnership and Social Inclusion}

Partnerships established for the betterment of slums tend to be more organic in nature. Partnerships involve interdependent, adaptable relationships between various actors based on trust and generally include entities other than the State. This third entity, such as a Non Governmental Organisation (NGO), is tasked with more socially oriented goals, such as creating procedures to integrate the slum settlement into its larger community (Chang, 2009). It is highly recommended to create partnerships involving the State, Non-Governmental Organisations, the private organisations, community agencies and slum dwellers in slum upgrading. Partnerships are essential in the successful and sustainable implementation of slum upgrading (Gulyani \& Debomy, 2002). Early slum upgrading projects mainly involved infrastructure provision without involvement, coordination or interaction with the target community. In as much as such projects improved the slums, the livelihoods of dwellers remained unaffected. It is argued that physical infrastructure improvements need to be coupled with improved opportunities for residents to become integrated citizens of society (Chang, 2009). Upgrading partnerships guarantee collective stakeholder involvement in the planning and implementation processes. Similarly the trustworthiness of stakeholders is another element of prime importance in settlement upgrading. There should be authentic reasons for involving or incorporating the various stakeholders in the upgrading process. Without valid motives there may not be a total stakeholder buy-in into the project (Danso-Wiredu \& Midheme, 2017).

The World Bank (2013) defines social inclusion as the process of improving conditions for marginalised individuals and groups to participate in society. The World Bank (2009) notes that at the city scale, efforts aimed at improving slum conditions by providing basic infrastructure and services have minimally impacted social inclusion. In the absence of institutional and complementary reforms it is unlikely physical and spatial interventions alone can foster social integration. Even though inclusion is based on access to affordable housing and services, it requires access to "the right to the city", livelihood opportunities and participation in decision making for the urban poor. Social inclusion can be at- 
tained by acknowledging and obtaining collective and individual citizens rights, guaranteeing participation for all in decision making and development, and improving health, safety and security. In order to achieve inclusion, it is vital that the urban poor and marginalized are recognized. Civil society likewise holds a pivotal role in fostering inclusiveness, through their ability to work directly with marginalised communities. NGO and community advocacy have been useful agencies for promoting social inclusion in development interventions at national and local levels. Huchzermeyer \& Karam (2006) also notes that affordability is an essential requirement for achieving social inclusion and tenure security. Affordable slum upgrading solutions protect the slum dwellers against displacement upon project completion. When the improved settlements formed by slum upgrading are unaffordable for the intended beneficiaries, exclusion is inevitable regardless of the original well intentioned objectives. Regularisation interventions are less likely to succeed without the full inclusion of the urban poor and other marginal communities in the planning of such initiatives.

3) Replicability of Strategies

Cohen (1983) was one of the first to advocate the need to create a framework which enables the multiplication of housing delivery systems and assists in the mobilization of resources for housing the urban poor without dominating or controlling the process.

Generally informal settlements are not homogeneous in character, as they vary even when located in close proximity. Slum upgrading strategies should therefore be uniquely suited to respond to the local specificities. Locally focused slum upgrading strategies have taken root and gained popularity in recent years. Non Governmental Organisations (NGOs) are one of the main stakeholders championing upgrading initiatives in the global south. They have been involved in developing place-specific slum upgrading interventions, which have triggered major urban transformation since each slum locality has its own challenges.

Development of specific interventions for a problem within each community appears to be the answer to the slum menace as opposed to generic solutions (Danso-Wiredu \& Midheme, 2017). Recent upgrading projects have developed specific principles, approaches, and upgrading typologies. Strategies have embraced key objectives for upgrading such as active community participation, resettlement without compensation, and the need for upgrading initiatives to stimulate economic development. Most accept the need for improvement across all sectors, but actual and perceived implementation difficulties mean that most projects still adopt a sectoral approach to meeting these needs. According to Satterthwaite, (2001) social relations are an essential element to consider in locally-specific slum upgrading projects because social relations and social settings differ from one community to the next. Set within social relations is an element of trust which binds together the community members and creates distinct norms and values. Stakeholders employ these social relations to devise appropriate and specific slum interventions (Danso-Wiredu \& Midheme, 2017). 
It is possible to rescale and replicate successful slum upgrading interventions. Where applicable the augmenting and replication of interventions should have due regard for existing built environment and focus of the specific needs of the target settlements. Project cost, construction materials, means of financing and tenure security are some of the successful strategies which can be replicated in other slums with similar settings. The literature shows that comprehensive strategies such as participatory approach to slum upgrading have been replicated (Muller \& Mitlin, 2007). Informal settlements do not have similar levels of deprivation therefore upgrading interventions should uniquely reflect the needs of the local communities. Similarly conditions for replication should be assessed against the local conditions where strategies are to be applied.

4) State and the Non Governmental Organisation Involvement

Governments have been key agents in settlement regularisation. This is despite years of previously adopting a laissez-faire attitude to the growth of informal settlements. Gulyani \& Connors, (2002) notes that African governments have, in the last 6 decades, made important contributions to slum upgrading. A diverse team of stakeholders often involved in the intricate exercise of comprehensive slum upgrading. The stakeholders in slum upgrading includes state actors, tenants, landlords and supporting agencies such as Non-governmental Organisations(NGOs), Civil Society Organizations (CSOs), the private sector and multi/bilateral development partners in varying combinations (Syagga, 2011). The State and civil society actors offer distinct strengths to settlement upgrading. Developing the alliances between these two main agencies is crucial in avoiding duplicity of efforts and waste of scarce resources. Government and stakeholder collaboration fosters effective execution of tasks, accelerates the process and allows for strategic use of partners strengths for better results. While governments are better placed to guide policy formulation and coordination, civil society has more experience in developing grassroots technical capacities, as well as building linkages between external actors and the local communities (Midheme, 2010).

Civic organisations have in recent times taken on a pivotal role in slum upgrading initiatives. They have shown the competence in grassroots and resource mobilisation for effective infrastructure and service provision in slum communities. They facilitate in highlighting to the state, the needs of slum communities and in lobbying for assistance from cooperating partners and donor agencies. Similarly the government's role in shelter provision is well documented as their functions cannot be substituted by any other actor. Local government, as government agents lead the design and implementation strategy and play a role in the management of upgraded settlements. UH-habitat estimates there are a several thousand civil agencies involved in housing delivery world-wide with almost half of them being part of a global network that works to promote UN-habitat programs for sustainable and affordable housing for all (Danso-Wiredu \& Midheme, 2017). Successful slum upgrading involves the concerted efforts of the state to formulate adequate policies and the fortitude to execute them. More in- 
novative approaches to slum upgrading should be the focus for future collaboration between the state, NGOs and slum dwellers.

\subsection{Informal Settlement Upgrading in Zambia}

Zambia faces housing and urban development challenges like many other developing countries. A lack of political will and clear development policies to tackle the challenges of a deterioration of urban physical environment and living conditions has resulted in the poor and other marginal populations devising solutions to their housing challenges.

This has culminated in the illegal occupation of land and growth of slums or informal settlements. The development and growth of informal settlements has occurred in tandem with rapid urbanization taking place in Zambia. The country has over $44 \%$ of the population concentrated in a few urban centres along the major transport corridors (Hampwaye \& Mweemba, 2012). Lusaka presently has 37 recognised informal urban settlements (See Figure 1). Over 70 percent of the urban population live in these settlements, which continue absorbing most of the urban growth and are characterized by poor living conditions and health threats (UN-Habitat, 2012).

Informal urban settlements or kombonis are areas occupied without right or legal title (Makasa, 2010). According to local statutes, these settlements are categorized into two main types: improvement areas (upgraded) and unrecognised settlements. The former are former slums that have been accorded legal title for occupation and provided with basic services like water, improved sanitation facilities, schools and roads. The residents are also given an opportunity to obtain occupancy Licences, which are renewable after 30 years. The latter are settlements that have not been granted legal title. Most of the slums are either located near the city centre in the proximity of industrial areas or in the outskirts of the city along the major roads. They are situated on areas meant for agriculture and housing development or flood prone areas which were categorized as unsuitable for human habitation.

Upgrading interventions in Zambia were initially based on infrastructure provisions with little focus on individual structures within the slum communities. With the help of the World Bank, the country conducted some infrastructural upgrading in selected informal communities, with the World Bank providing funding in 1974 to upgrade selected informal settlements in Lusaka. This was based on the Bank's newly introduced policy on funding urban development in developing countries. The Lusaka Squatter Upgrading Project (LSUP) was one of the pioneering upgrading programmes in Africa under this initiative (Gulyani \& Connors, 2002). The programme involved the provision of basic housing infrastructure, community services and loans for building materials and land tenure security by facilitating for land regularisation and titling. As support, the Government passed the Housing (Statutory and Improvement Areas) Act of 1974 


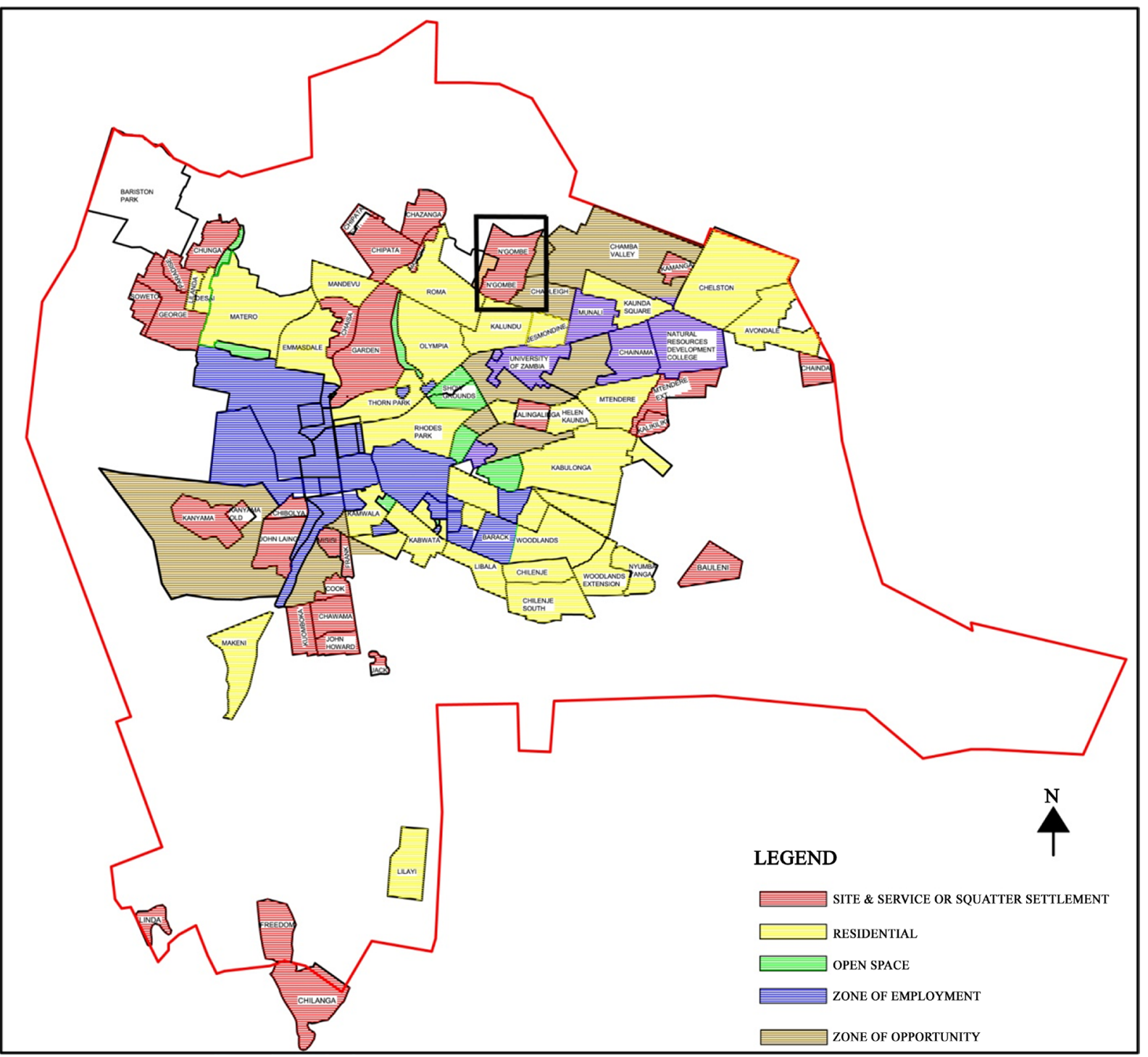

Figure 1. Distribution of informal (squatter) settlements (shown in red) in Lusaka. Source: Lusaka District Planning Office Data, 2010.

which empowered local councils to give squatters tenure security and provide basic social facilities in informal settlements. It gave councils the opportunity to declare these settlements as Improvement Areas. The Improvement Area declaration meant, residents could now be issued with 30-year Occupancy Licenses, while the area goes through the process of upgrading. The licences carried the same effect as the landowner obtaining a direct lease of the land from the state and could later be replaced by certificates of title. Owners were only allowed one property in an Improvement Area and no commercial activities on residential lots were permitted.

\section{Methodology}

The methodology of this empirical study rests on a case study strategy with a 
qualitative approach. This method allowed for the incorporation of a variety of data sources and tools for analysis and interpretation and is an appropriate empirical inquiry for investigating a contemporary phenomenon within its existing context (Creswell \& Clark, 2017: p. 4). Qualitative methodology is used to gain a deeper understanding of the respondents' views and their experiences about the community being studied. Empirical data were collected from households in Ng'ombe informal settlement of Lusaka. Ng'ombe informal urban settlement offers a data rich setting based on its location in the city of Lusaka, upgrading interventions conducted in the settlement, observable and measurable outcomes of development interventions in the settlement and its general relevancy to the objective of this study (Neuman, 2011). The article findings are based on study results and interviews conducted by the author in Lusaka, Zambia between June 2013 to February 2014 and a reassessment visit in March to June 2018.

\subsection{The Study Area: Ng'ombe Informal Urban Settlement}

Ng'ombe settlement started as a workers compound on a farm in 1930's colonial Northern Rhodesia now called Zambia. After Zambia's independence in 1964, migrants from other parts of the City joined in the occupation of the settlement. By 1970 the population in the area had increased and the housing development had expanded without the guidance of city planners or provision of any public utilities.

Ng'ombe is situated on the north-eastern edge of present built up area of the city of Lusaka. It shares boundaries with low-density planned settlements to the south, south-east, northern and western sides of the settlement as indicated in Figure 2. The settlement covers an area of 91.26 hectares and consists of the three distinct areas of Old Ng'ombe, New Ng'ombe and Ng'ombe-Kasisi. The

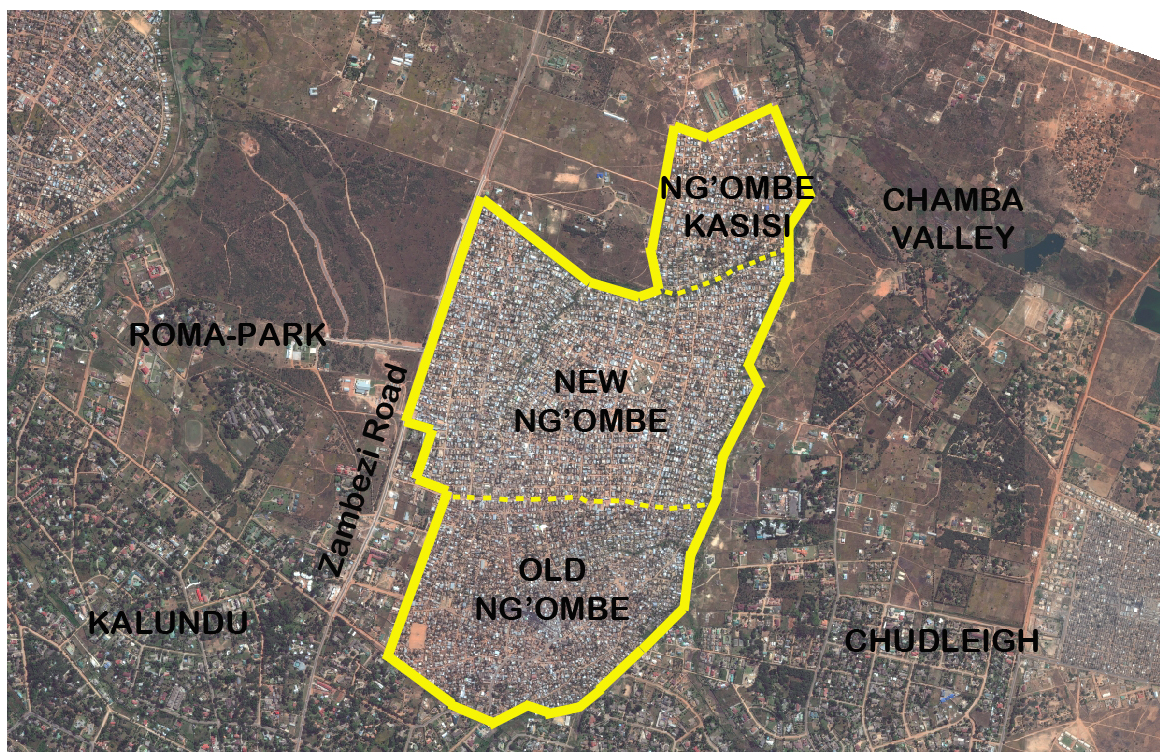

Figure 2. Aerial view of Ng'ombe and surrounding Areas. Source: Lusaka District Planning Office Data, 2010. 
population of the settlement is estimated at 92,000 and the average household size is 15.2 (LCC, 2012). The population of the settlement continues to grow spurred on by high birth rates and migrants from other areas. The households are divided into 235 blocks with each block having about 26 households. In Old Ng'ombe, the houses still retain a haphazard layout and are located very close to each other. The majority of houses are made of mud bricks with old and dilapidated iron roofing sheets. Some of the houses have their roofs covered with plastics or have big stones placed on top to prevent rain from going in or the roof from being blown off by wind. In the section, houses are well arranged and better constructed of modern durable materials such as concrete blocks and galvanised iron roofing sheets. While Ng'ombe-Kasisi is the most recent part of the settlement, that started as a settlement on illegally occupied land across the stream north of New Ng'ombe. The houses in this part of the settlement are generally built of more durable materials and plot sizes retain a formal grid pattern that defies its illegal origins.

The participatory slum upgrading program officially called Ng'ombe Upgrading and Poverty Reduction Project executed in Ng'ombe informal urban settlement is used as the case study for assessment, since there is tangible evidence that the regularisation interventions yielded relative success which can be observed and reviewed for this study.

\subsection{Data Collection}

A two-stage process of this study made use of qualitative data collection methods. The first stage consisted of purposively selected 24 in-depth qualitative interviews and 8 key informant interviews to explore and identify key factors involved in settlement upgrading. Structured in-depth interviews with 8 key civic officials and 24 key community informant interviews were conducted to enquire about the level of state and NGO participation in informal urban settlement development. The city planning and public service managers from the Local Government and Housing Ministry, Lusaka District and city Planning Office and department heads at Lusaka City Council involved in the urban planning, public service provision and implementation of development intervention mechanisms in informal settlements were interviewed. Key informants include elected resident representatives, community-based organizations (CBOs) and NGOs working in the community.

In the second stage, a survey was conducted with the aim of establishing the dweller's perceptions of conditions in the settlements after the regularisation. Deliberate sampling was adopted in order to have purposive and unbiased selection of study samples ensuring only pertinent information was collected for the study rather than statistical generalization (Kothari, 2004: p. 178). Deliberate sampling involves purposive selection of study units of the universe in forming a representative sample of the universe. Purposive sampling allowed for maximising what can be learnt from information rich cases, about issues pertinent to the 
study (Stake, 1995). The areas for in-depth study (clusters) were selected by way of preliminary survey of the area and review of aerial photographs. The dwellings in Ng'ombe are single storey and each cluster has approximately 50 dwellings. 5 clusters of almost 50 households each were selected as a sample of the 6044 households of the settlement population. Representative clusters within Ng'ombe were selected as a representation of the whole settlement population. The criteria used in identifying the clusters included areas where upgrading interventions were in close proximity, the physical characteristics of the buildings, network of roads and footpaths and localities with activities such as commercial, recreation, and sanitation and existing public facilities. The reason for opting to carry out the study in clusters was because the cluster offered a manageable sample to carry out qualitative study of the environment and the dwellers within a defined neighbourhood space, observing the ordering of space and related activities (Kothari, 2004: p. 178).

The case study data were collected from the sampled households using structured questionnaires. The questionnaire was designed to enable collection of primary data on respondent households. In the questionnaire, the respondent households provided information regarding property ownership status, household composition, duration and reasons for staying in the settlement, their views on aspects of quality of communal and neighbourhood public spaces, infrastructure and services, community participation and current intervention strategies. The questionnaires helped establish the historical development of Ng'ombe. They highlighted changes in land use in the settlement and housing development. They provided narratives on the physical and social development of the areas. The interviews were conducted in English, Chibemba or Chinyanja (local languages) depending on the language the respondent was comfortable using. Each interview lasted for about 15 to 30 minutes depending on the respondent's ability to understand the questions. Some respondents were engaged in livelihood activities during the interviews. This information helped provide an indication to which research findings could be generalized beyond the realm of the case study under examination. Respondents in the selected households had to be residents of Ng'ombe and had to give consent to the interview.

The research instruments used include desk top research from primary and secondary written sources were used to develop a deeper understanding of the study subject (Yin, 2003). Data were analysed through qualitative documentary analysis. This involved the use of published books, research articles and Zambian government policy documents. Direct observation and photographic documentation complimented the key research methods and provided more explanatory power to understanding life in Ng'ombe (Peimani \& Kamalipour, 2016).

\subsection{Data Analysis}

The questionnaires had both open-ended and closed ended questions. Open-ended 
questions have been included to provide an opportunity for residents to elaborate their views on specific issues, which also provided an opportunity for the interviewer to probe specific responses that were not as detailed as required. Open-ended interviews embodied interesting reflections on policies affecting informal settlements, urban policies, and the role of local authority in supporting social and built environment processes in the informal settlements and to further explore the research themes. Interviews with housing experts and were conducted to establish the current, past and envisaged policies on upgrading interventions.

\subsection{Reliability and Validity}

A case study protocol was prepared to address threats to the reliability of case study research. It was intended to guide in carrying out the case study. The protocol content included; a case study project overview; procedures for the field; case study questions and; a guide for the case study report (Yin, 2003). Besides the case study protocol, only graduate research assistants from the University on Zambia in Lusaka were engaged to guarantee reliability and quality of data collected. The research assistants were trained in order to develop a common understanding of research issues, objectives and methods before commencement of fieldwork assignments. Likewise all questions for interviews were scrutinized in order to have a common understanding and interpretation of responses. Trustworthiness and validation was achieved by continuous field engagement, triangulation by using multiple data sources and rich thick description adopted in the article (Creswell \& Clark, 2017).

\section{Assessing the Elements in the Context of Informal Settlement Upgrading in Zambia}

\subsection{The Ng'ombe Community Participatory Upgrading Project}

Ng'ombe has over the course of its growth undergone a number of upgrading interventions (See Table 1). The Ng'ombe Upgrading and Poverty Reduction Project under review in this paper was undertaken with the assistance of a partnership between Human Settlements of Zambia (HUZA), the Royal Norwegian Society for Rural Development (NORCOOP) and the Norwegian Federation of Cooperative Housing Associations (NBBL), on the one hand, and the residents of Ng'ombe settlement on the other in 1996. The HUZA served as the facilitating agency in the settlement, while the NORCOOP made funds obtained from and Norwegian Agency for Development Cooperation (NORAD) available to HUZA. NBBL also contributed financially as well as professionally (Mulenga, Anyamba, \& Nordahl, 2004).

To facilitate the upgrading and poverty alleviation project, the HUZA employed the concept of "Community Participation" in settlement improvement. Community participation entails stimulating the sense of pragmatism and self-help 
Table 1. Upgrading projects undertaken in Ng'ombe informal urban settlement.

\begin{tabular}{|c|c|c|}
\hline Project Sector & Details & Ng'ombe Settlement \\
\hline Water Supply & $\begin{array}{l}\text { Provision of clean drinking } \\
\text { water }\end{array}$ & $\begin{array}{l}\text { - Pilot project with } 70 \mathrm{~m} \text { deep borehole } \\
\text { - Creation of Water Trust to manage water } \\
\text { extraction, treatment, distribution and } \\
\text { maintenance }\end{array}$ \\
\hline Road \& Drainage & Road and side ditches & $-1^{\text {st }}$ priority road of 630 metres \\
\hline $\begin{array}{l}\text { Income } \\
\text { Generation }\end{array}$ & Micro-credit scheme & $\begin{array}{l}\text { - Human Settlements Zambia (HUZA) is still } \\
\text { working in the settlement } \\
\text { - CARE PULSE program initiated by CARE } \\
\text { International-Zambia }\end{array}$ \\
\hline \multirow[t]{3}{*}{$\begin{array}{l}\text { Health \& } \\
\text { Sanitation }\end{array}$} & $\begin{array}{l}\text { Environmental health and } \\
\text { sanitation education program }\end{array}$ & - Construction of community health post \\
\hline & $\begin{array}{l}\text { Home latrine development } \\
\text { program }\end{array}$ & $\begin{array}{l}\text { - Community health education \& school health } \\
\text { service }\end{array}$ \\
\hline & Family planning services & $\begin{array}{l}\text { A planned parenthood initiative to offer family } \\
\text { health services in the settlement }\end{array}$ \\
\hline Education & $\begin{array}{l}\text { Community school } \\
\text { enhancement }\end{array}$ & $\begin{array}{l}\text { - Construction of a basic school facility by govt. } \\
\text { - Zambia Open Community Schools (ZOCS) } \\
\text { - Church supported community Schools }\end{array}$ \\
\hline
\end{tabular}

Source: LCC, 2012; World Bank, 2002; LCC; Amuah, 1999.

in the targeted communities. The primary aim being to ensure that the targeted communities begin to organise and mobilise themselves for improved and sustained living conditions (Mulenga, Anyamba, \& Nordahl, 2004). HUZA first began advocacy work in Ng'ombe in 1989, when it begun to support mobilisation of the residents to "agitate" for the recognition of their settlement as an improvement area. As a result of these activities, the residents of Ng'ombe established a Resident Development Committee (RDC) in 1996. A participatory needs assessment later coordinated by the RDC showed that the priorities of the residents of Ng'ombe were: access to clean water supply; health centre; better solid waste management; better roads and access to skills training and funding to enhance livelihood activities of the poor residents in particular.

In response to these, HUZA undertook to support construction of a health centre, skills training centre and provision of a micro-credit scheme to support the income generating activities of the poor. Other initiated poverty reduction programmes included the improved security lighting at the community market. In addition, HUZA started the only pre-school in the settlement to help prepare children for primary education. The latter was crucial, as there was no Government school in the settlement at the time and children had to compete for places in the nearby Olympia Basic School. HUZA also provided skills training programmes to residents, which skills were later used during the upgrading exercises. Construction of a health centre and skills training centre were also started at the same time. A number of boreholes were also sunk with the financial support from NORAD, NBBL and NORCOOP. The training offered to the RDC 
members enabled them to attract other agencies interested in supporting improved living conditions in Ng'ombe. In particular, the Rotary Club contributed in uplifting living conditions by sinking three boreholes in the settlement. The Lusaka Water and Sewerage Company also sunk some boreholes to help alleviate the water problem. Figure 3 shows typical water infrastructure constructed in the settlement during upgrading. The Planned Parenthood Association of Zambia also entered the area and began offering family planning services to the residents (Mulenga, Anyamba, \& Nordahl, 2004).

\subsection{General Characteristics of Ng'ombe from Household Sample}

The sampling frame is improperly balanced in terms of gender with more male respondents (79.9\%) than their female counterparts (see Table 2). This was mostly due to the tendency for most female respondents claiming to have a male head for fear of losing their properties. The sample indicated that about $62 \%$ of the respondents were property owners in the settlement and $40.6 \%$ of respondents having spent over 21 years in the settlement. The settlement appears to show low resident turnover which indicates a stable population. Most respondents attributed this to the low rentals charged (75\%) and the proximity to livelihood opportunities (21\%). This is despite the current lack of state regulation on rental charges and a lack of state rental housing for the urban poor. The information also shows that most $(72.5 \%)$ of respondents have had a minimum of primary level education (see Table 2). The survey has been employed to provide a demographic make-up of the settlement.

Most respondents were satisfied with the spatial conditions in the settlement (88.9\%). Respondents noted that there was adequate space for domestic and public activities such as crop cultivation, trading and food preparation. The respondent unsatisfied with the spatial environment tended to be located in the Old Ng'ombe part of the settlement which is plagued by environmental challenges due to the limited upgrading in this part of the settlement from inception.
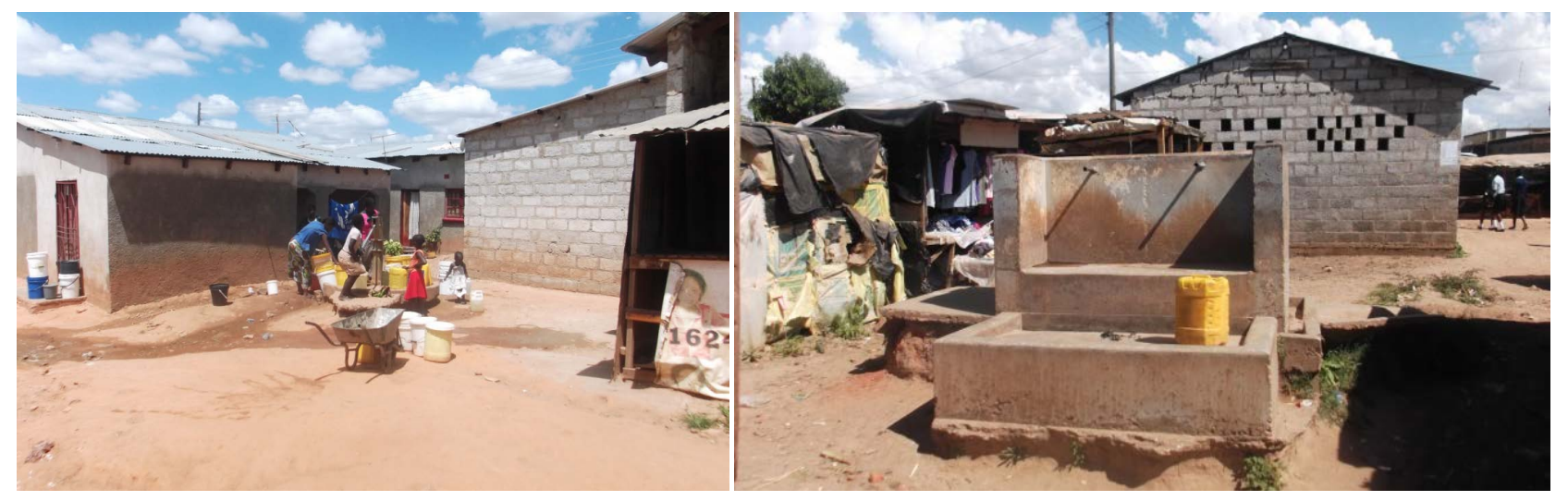

Figure 3. A borehole hand pump and disused water stand managed by the water trust in New Ng'ombe constructed during the upgrading process. Source: Author. 
Table 2. Socio-economic survey of Ng'ombe household respondents.

\begin{tabular}{|c|c|c|c|}
\hline Variables & Percentage & Variables & Percentage \\
\hline Gender of Household Head & & Highest Education Attained & \\
\hline Male & 79.9 & No formal education & 27.5 \\
\hline Female & 20.1 & Primary education & 51.2 \\
\hline Age & & Secondary education & 20.1 \\
\hline Under 35 & 41 & College & 1.2 \\
\hline Above 35 & 59 & University & - \\
\hline Marital Status & & Duration of Stay in Ng'ombe & \\
\hline Unmarried & 64.3 & Below 5 years & 10.2 \\
\hline Married & 35.7 & $6-10$ years & 9.4 \\
\hline Position & & $11-15$ years & 12.7 \\
\hline Landlord & 62 & $16-20$ years & 27.0 \\
\hline Tenant & 38 & Above 21 years & 40.6 \\
\hline Household income & & Reason for Staying in Settlement & \\
\hline 0 to 999 & 35.2 & Affordable Rent & 75.0 \\
\hline 1000 to 3999 & 42.2 & Affordable Rent/Proximity to work & 3.7 \\
\hline \multirow[t]{2}{*}{ Over 4000} & 22.6 & Self employment & 12.3 \\
\hline & & Proximity to self employment & 9.0 \\
\hline Resident's Spatial Needs Met? & & Is Accommodation Satisfactory? & \\
\hline Yes & 88.9 & Yes & 92.6 \\
\hline No & 11.1 & No & 7.4 \\
\hline
\end{tabular}

Source: Author's compilation.

\subsection{Situating Ng'ombe in the Context of the Settlement Upgrading Elements}

\section{1) Land Tenure Security in $\mathrm{Ng}$ ombe}

Originally land in Ng'ombe was privately owned by a single landlord with all occupants on the farm being considered illegal occupiers. Through the community advocacy pioneered by HUZA, Ng'ombe has been recognised as an improvement area. It was legalized on 16th February, 1999 by the Ministry of Local Government and Housing (MLGH) under Statutory and Improvement Areas Act (Yasini, 2007). The residents of Ng'ombe are now entitled to apply and be issued with occupation licences. The occupancy licence serves as the legal documentation for the ownership of both their land and property in the declared informal settlements. The Lusaka City Council as a partner in the upgrading process undertook to ensure that the settlement was declared an improvement area in order to ensure security of tenure for the residents. Recognition was, however, not only important for provision of essential infrastructure and services, but for ensuring social stability as well. During the survey it was observed that tenure 
security has led to the mushrooming of an informal market in structures in the community which the local authority appears to tolerate albeit encourages. Tenure provision has also improved the local authority capacity to collect more public revenue. Tenants on the other hand expressed misgivings on regularisation of the settlement as it has led to increase rental charges in the community leading to displacement of some of the original tenants. Landlords and property owners acknowledged during the survey that they are now better placed to make extensions and improvements to their buildings without fear of future demolition or eviction. Figure 4 shows a residential building being extended after the owner had obtained legal tenure documents from the local council.

\section{2) Partnership and Social Inclusion in Ng'ombe}

The Ng'ombe participatory slum upgrading project involved all relevant stakeholders in all stages of the project; the local coordinating organization (HUZA); the State through the Lusaka City Council; the international donors and the local community. HUZA, being a small NGO with limited funds, was determined to empower the diverse set of residents with the idea that it was within their power to improve living conditions in their settlement. HUZA thus developed a people centred community participation strategy. The community participation approach implemented by HUZA relied on limited resources that were made available by NORAD, NBBL and NORCOOP, which was no more than US\$200,000. To deliver the improvements of the scale achieved in, Ng'ombe, HUZA had to stick to the priorities identified by the residents of Ng'ombe. HUZA thus focused on creation of community institutions to provide leadership and ensure sustainability of the improvements. Other areas of focus were improvement of access to health service, clean water supplies, provision of practical skills and micro credit. These sought to improve the livelihoods of the residents in order to guarantee the sustainability of the improvements, as well as to reduce vulnerability and human suffering that goes with extreme deprivation. Direct participation of all the residents in the upgrading activities was also necessary to guarantee ownership and sustenance of the intervention. It was also regarded as an insurance
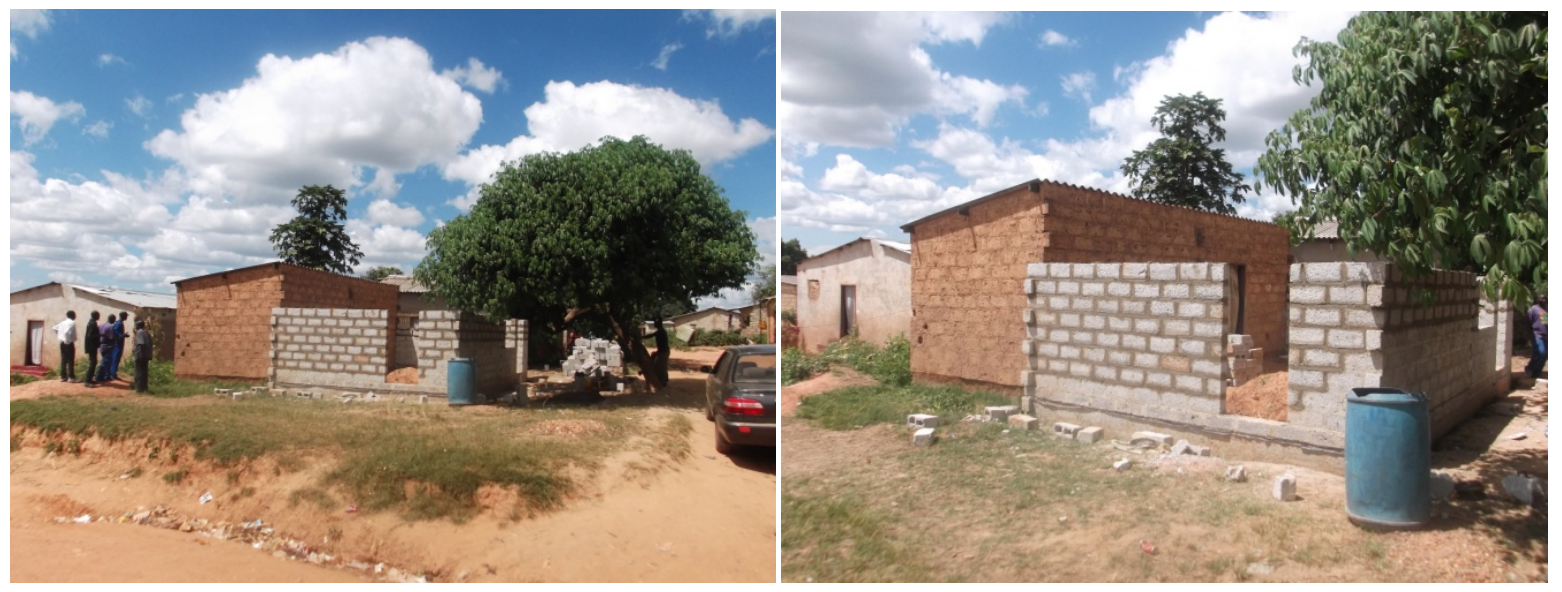

Figure 4. Showing a dwelling being extended after the owner obtained an occupancy license. Source: Author. 
against vandalism and promotion of a sense of solidarity. The residents were therefore encouraged to provide free labour in the construction of roads, health centre and community skills training centres, as well as in the work relating to improvement of the water supply.

It was noted from the survey that social relations among Ng'ombe residents are no different from other communities found in the country. Ng'ombe like other settlements is a multi cultural settlement with no evidence of the settlement being shared or settled along tribal lines which made social organisation in the community easy. HUZA successfully facilitated establishment of Residents Development Committees (RDC) in Ng'ombe. RDCs are community-based institutions that have taken responsibility of the development of the settlement. They are recognised as the entry point for the local authority and other public service providers into the settlement. The involvement of the community members ensured social inclusion in decision making and their physical contribution as casual workers in carrying building materials, utilizing local knowledge and generating skills required for project maintenance, helped save cost. Social inclusion in the implementation process, when combined with specific initiatives to address social issues, helped to increase trust and confidence in the new infrastructure, and fostered new partnerships within neighbourhoods. Urban problems were addressed by a participative-collaborative management structure between the local government and Ng'ombe residents, and rather than focusing only on infrastructure like roads and housing, social issues were also addressed. Though limited in scope and application this case offers an interesting model for achieving social cohesion, community appropriation and sustainability in slum upgrading.

3) Replicable Strategies in Ng'ombe

Attempts at replicating successful upgrading projects from one context to another must first recognise the variability in social relations, opportunities and constraints. For instance a major aspect of the community participation based upgrading, which has had a long term impact on the development of Ng'ombe and individuals targeted is capacity building. Individuals who had received training in different skills were empowered in terms of acquiring practical skills needed on the labour market. The number of beneficiaries in the HUZA's community development strategy was also high in the sense of improved living condition, but not in the sense of housing allocation. It has been argued that though the approach might encourage and partly facilitate the process for a great bulk of residents' effort of improving their living conditions, there however is no evidence that this approach actually leads to any substantial production of new houses (Burgess, 1997).

The occupancy certificate tenure model adopted in Ng'ombe was an innovative system of land administration that carries a lot of promise in the provision of low-income housing in urban areas. The security of tenure it provides for home owners offers a sense of surety that permanent improvements they undertake on their properties will not be easily lost by demolitions or evictions as was 
the case previously. Maintenance of infrastructure and services in informal urban settlements in Lusaka is inadequate at best and mostly nonexistent. The community participatory upgrading creates a better chance of adequate maintenance in the future. In Ng'ombe upgrading, the created community Water Trust (WT) has the distinction of being almost entirely managed by the community. This includes responsibility for the technical, financial, and customer relations. Lacking, however, is a mechanism to ensure that sufficient funds are generated for adequate maintenance including replacement.

The formation of the RDC in Ng'ombe was a result of a "trial and error" mechanism of finding out which organisational structure proves to be the most sustainable way of organising the residents. The history of party organisation in Zambia played an important role in the first model of organisation. Since independence the political parties had been important in the administration of slum and other residential areas (Mitullah et al., 1994). Building on the experiences of drawing a fixed interface between the local party organisation and the area based residential organisation, Lusaka City Council developed a guiding constitution for the RDC, stating their mandate. The constitution underlined that the concept of community participation had been endorsed by both Central government and the Local authority as an essential strategic element in a project designed to improve living conditions for most low-income groups, and particularly in upgrading projects of informal settlements (Mulenga, Anyamba, \& Nordahl, 2004).

From a project financing perspective, the slum upgrading tends to follow a government "subsidy" approach. In this project and as with previous projects, no attempt was made to recover any of the capital costs of infrastructure provision, down to the secondary and tertiary or local infrastructure. The ability to replicate the financing model of Ng'ombe upgrading is thus questionable and can only work where government has funds (often supplied by donors) to finance a subsidy. Given the extreme poverty that exists, this approach which is also prevalent in many other places may be unavoidable. It is therefore critical that the standards and service levels provided do not exceed what is necessary to serve particular communities.

4) Collaboration between Government and Civic Organisations

The recent research has questioned Turner's theory of minimalist state engagement in informal settlement upgrading, arguing on the contrary for a strong state in order to ensure clear property rights, land acquisition and secure tenure. Gulyani \& Connors, (2002) observe that most African states have always held a pivotal role in upgrading. The Ng'ombe upgrading under the stewardship of HUZA likewise collaborated with the state, donors and local community to ensure that the project was undertaken successfully. HUZA canvassed the entire community to mobilise the dwellers. Unlike in other settlement upgrading initiatives, in which either the state or NGOs sought to work independently with the affected communities, often with little involvement of each other, the Ng'ombe upgrading presented a paradigm shift towards stronger partnership between the 
community and local government. The Lusaka City Council (LCC), as local authority, was actively engaged in the project. Through its Department of Housing and Social Services, the City Council refocused two directorates, one responsible for formal housing and the other for peri-urban informal settlements. The LCC has generally been the responsible agency for implementing upgrading initiatives. More recently, support agencies have made an effort to work together and coordinate on interventions and to get a measure of consistency in upgrading programs. This makes the work of coordination and maintaining consistency critical. Carrying out works together often avoids the case of one sector initiative being disrupted by a subsequent initiative. Thus, apart from the need for upgrading schemes to be visible and to create an impact to assist community and government "buy-in" hence improving the chance of sustainability (e.g. for maintenance, communities paying dues and authorities making budgets) there are also strong technical arguments for a more collaborative sectoral or integrated approach to upgrading (World Bank, 2002).

\section{Conclusion}

The living conditions found in informal settlements limit the residents' ability to improve their lives. NGOs such as HUZA believe that improvement of living conditions is the key to the reduction of poverty and human suffering. Improving lives of poor people requires their direct involvement and participation in decision-making and implementation of projects identified by the beneficiaries themselves. HUZA operates on the premise that community participatory upgrading where residents are involved in the implementation of projects reduces implementation costs, while the participation of local communities ensures their commitment and ownership of the projects. The strategy has the benefit of promoting democracy, as it requires participation of residents in key decision-making, both directly and indirectly through participatory need assessments and as elected officials of the community institutions established to coordinate settlement development. The importance of community involvement in decision making and in setting out affordable and sustainable upgrading priorities is commonly acknowledged. Stakeholder inclusion must be regarded as a key tenet of successful upgrading. The provision of tenure security likewise is recognised as a foundation of sustainable and inclusive upgrading. Without clear land ownership, it is difficult to convince the residents to pay for public services and to make improvements to their dwellings. Land tenure provision can be successfully implemented if the community is involved in the regularisation processes. Slum upgrading can be replicated if the interventions fit in a different community. Provision of social services and community infrastructure is commonly replicable and appears to be a favoured form of upgrading approach. The choice of settlement upgrading approach to implement should consider the local community's ability to implement and sustain the selected approach. Civil society engagement in the settlements encourages collaboration among the various 
stakeholders. The composition of civil society is different in each project, but often community leadership roles are in the hands of leaders of Resident Development Committees (RDC) or some other forms of social enterprise formed mainly to manage social services in the community such as the Water Trust in this case. The role of the state in slum upgrading remains equally vital. The state is the main agent for bringing development to slum settlements and is the implementing agency in upgrading initiatives. The state has the advantage of being the only stakeholder able to significantly improve the livelihoods of the urban poor by putting in place policy and legislation such as providing tenure security, to support settlement upgrading. What remains critical is the need for the state to pivot from a top-down to a bottom-up approach in planning development interventions in informal urban settlements.

The Ng'ombe upgrading initiative brought together multiple stakeholders drawn from the state, international and local private sector and civil society in a joint effort to improve social and economic situation of the urban poor. Individual projects in upgrading can be successfully delivered, but much more important is what happens when the various stakeholders have disengaged from the project. The community micro credit scheme and skills development initiatives ensured that not only were the local community provided with public infrastructure, they were also equipped with the skills and finances needed to ensure management and maintenance of the provided physical infrastructure could be sustained. To ensure the long-term sustainability of community infrastructure, it is necessary to develop income-generation activities to support their operation and maintenance as was the case in the Ng'ombe upgrading. Similarly the project also emphasised the need for operation and maintenance costs of infrastructure provided in upgrading programmes to be by shared responsibility between the NGOs, the CBOs, the municipal authorities, and the community. As was the case in this study, funds for adequate operation and maintenance including replacement must be generated either through community structures or in conjunction with local authority and commercial utility structures. Stakeholders managing upgrading interventions need to consider the merits of incorporating these elements before planning and implementation commences. Each of the identified elements is critical in the upgrading process. International and local NGOs initiatives towards improving the housing situation on the urban poor can appreciably contribute towards reducing the housing problem and can generally improve their livelihood conditions. This combined with state collaboration can allow for the replication and up-scaling of community interventions. The Ng'ombe upgrading provides evidence that the urban poor when provided with the necessary support can make significant investments to improve their housing situation.

\section{Deficiencies and Future Direction}

The case study and analysis did not provide an in-depth study of dynamics and 
conditions at dwelling level as this was beyond the scope of the research. However after completion of the research it was observed that the study of the settlement dynamics at dwelling level would be necessary for future research as it would guide the formulation of intervention and planning regulations of dwellings and other infrastructure in informal settlements. A few of the respondents exaggerated some of the responses, during the data collection, on the misconceived premise that this survey was a veiled government exercise to identify members of the community who required assistance with individual shelter upgrading. It was also not possible to capture the real picture of urban poverty levels in the settlements as some residents did not want to be portrayed as being poor, which might affect the resulting data collected. Despite providing carefully structured interview questions, it was sometimes difficult to convey the intended meaning when translating questions to the respondents in the informal settlements due to the numerous local languages spoken.

Other elements beyond the scope of this research were observed during the course of the study but are important for further understanding of informal urban settlement conditions. It would be ideal to conduct further research on the impact of upgrading at the dwelling level in order to develop effective solutions to the accommodation needs of the individual households in informal settlements. The impact of poverty on informal settlement built environment was also not fully explored and would be an ideal area requiring further research. Further research in the general area of physical regularization of informal settlements in Lusaka is needed to establish which of the existing settlements should be maintained and upgraded and which settlements to relocate. Another issue requiring further investigation is the assessment of the effects that gentrification is having on the development of informal settlements of Lusaka. It is important that a study of the effect middle income residents to informal areas are having on the physical, economic and social settings of the settlements is investigated.

\section{Conflicts of Interest}

The authors declare no conflicts of interest regarding the publication of this paper.

\section{References}

Amuah, A. K. (1999). CARE Peri-Urban Lusaka Small Enterprise (CARE PULSE) Project Zambia. Africa Region Findings \& Good Practice Infobriefs. World Bank Publications. http://hdl.handle.net/10986/9851

Burgess (1997). Neoliberalism and Urban Strategies in Developing Countries. London: Zed Books.

Chang, T. (2009). Improving Slum Conditions with Public-Private Partnerships. Panorama. http://www.shram.org/uploadFiles/20140609033101.pdf

Cities Alliance (2006). Guide to City Development Strategies: Improving Urban Governance. Washington DC. 
Cohen, M. (1983). The Challenge of Replicability. World Bank Reprint Series No. 287, Washington DC: World Bank.

Creswell, J. W., \& Clark, V. L. P. (2017). Designing and Conducting Mixed Methods Research. Thousand Oaks, CA: Sage Publications.

Cronin, V. (2012). Slum Upgrading in India and Kenya: Investigating the Sustainability. Cambridge: University of Cambridge. http://ethos.bl.uk/OrderDetails.do?uin=uk.bl.ethos.550171

Danso-Wiredu, Y. E., \& Midheme, E. (2017). Slum Upgrading in Developing Countries: Lessons from Ghana and Kenya. Ghana Journal of Geography, 9, 88-108.

Du Plessis, R. (2017). Navigating the Complexities of Slum Upgrading. Darmstadt: Mundus Urbano.

Durand-Lasserve, A., \& Clerc, V. (1996). Regularization and Integration of Irregular Settlements: Lessons from Experience, Urban Management Programme. Working Paper Series 6, Nairobi: Undp/Unchs/World Bank Ump.

Gilbert, A. (2007). The Return of the Slum: Does Language Matter? International Journal of Urban and Regional Research, 31, 697-713. https://doi.org/10.1111/j.1468-2427.2007.00754.x

Gulyani, S., \& Connors, G. (2002). Urban Upgrading in Africa: A Summary of Rapid Assessments in Ten Countries. Africa: Regional Urban Upgrading Initiative Africa Infrastructure Department. Washington DC: The World Bank.

Gulyani, S., \& Debomy, S. (2002). Upgrading Low Income Settlements. Country Assessment Report, Washington DC: Aftu.

Hampwaye, G., \& Mweemba, L. (2012). Chapter 15: Zambia Country Profile. Southern African Regional Universities Association, SARUA Publication.

Huchzermeyer, M. (2011). Cities with “Slums". From Informal Settlement Eradication to a Right to the City in Africa. Claremont, CA: UCT Press.

Huchzermeyer, M., \& Karam, A. (2006). Informal Settlements: A Perpetual Challenge? Cape Town: UCT Press.

Kothari, C. R. (2004). Research Methodology: Methods and Techniques (2nd ed.). New Delhi: New Age International (Pty) Ltd.

Krajisnik, M. (2011). Assessment of Strategies for Secure Tenure, Tenure Policy and Housing: As Means of Advocating Sustainable Development in Developing Nations. M.sc. Thesis, Uppsala: Uppsala University.

Lusaka City Council (2012). Land Information Management for Chaisa: Chaisa Pilot Initiative. Lusaka: LCC.

Lusaka District Planning Office (2010). Lusaka Built-Up Coloured Model. Lusaka: Lusaka City Council Documents.

Makasa, P. (2010). The 1996 Zambia National Housing Policy. Delft: Delft Centre for Sustainable Urban Areas, Delft University of Technology.

Midheme, E. P. O. (2010). Laying the Foundations for the "Just City" Collaborative Spatial Planning and Settlement Upgrading in Voi, Kenya. Master's Thesis, Leuven: Katholieke Universiteit.

Mitullah, W., Mulenga, C. L., \& Simonsen, J. K. (1994). The Upgrading of Bauleni Settlement in Lusaka. Norwegian Centre for Cooperative Development (Norcoop), the International Section of the Royal Norwegian Society for Rural Development.

Mukhija, V. (2002). An Analytical Framework for Urban Upgrading: Property Rights, Property Values and Physical Attributes. Habitat International, 26, 553-570. 
https://doi.org/10.1016/S0197-3975(02)00019-X

Mulenga, C., Anyamba, T., \& Nordahl, B. (2004). Upgrading of Urban Informal Settlements: Evaluation and Review of Upgrading and Poverty Reduction Activities in Three Settlements in Lusaka, Zambia. Project Report 365, Oslo: Norwegian Building Research Institute.

Muller, A., \& Mitlin, D. (2007). Securing Inclusion: Strategies for Community Empowerment and State Redistribution. Environment and Urbanization, 19, 425-439. https://doi.org/10.1177/0956247807082822

Neuman, W. L. (2011). Social Research Methods: Qualitative and Quantitative Approaches (7th ed.). Boston, MA: Pearson.

Peimani, N., \& Kamalipour, H. (2016). Where Gender Comes to the Fore: Mapping Gender Mix in Urban Public Spaces. Spaces and Flows. An International Journal of Urban and Extra Urban Studies, 8, 19-30. https://doi.org/10.18848/2154-8676/CGP/v08i01/19-30

Satterthwaite, D. (2001). From Professionally Driven to People-Driven Poverty Reduction; Reflections on the Role of Shack/Slum Dwellers International. Environment and Urbanization, 13, 135-138. https://doi.org/10.1177/095624780101300210

Singh, K. A. (2014). Urban Slums: An Enquiry into Concept, Characteristics and Policy Interventions. Varanasi: Banaras Hindu University.

Stake, R. E. (1995). The Art of Case Study Research. Thousand Oaks, CA: SAGE Publications.

Syagga, P. (2011). Land Tenure in Slum Upgrading Projects (pp. 103-113). Les cahiers d'Afrique de l'Est, IFRA Nairobi.

UN-Habitat (2003). The Challenge on Slums: Global Report on Human Settlements (No. Hs/686/03e). Millennium Development Goals (Mdg), General. Unchs, Counries.

UN-Habitat (2008). The State of African Cities: A Framework for Addressing Urban Challenges in Africa. Nairobi: Un-Habitat \& Unep.

UN-Habitat (2012). Zambia Urban Housing Sector Profile. Housing Sector Profile Series. Shelter and Sustainable Human Settlements Development Division. Nairobi: UNON, Publishing Services Section.

UN-Habitat (2014). The State of African Cities 2014: Re-Imagining Sustainable Urban Transitions. Nairobi: United Nations Human Settlements Program.

Werlin, H. (1999). The Slum Upgrading Myth. Urban Studies, 36, 1523-1534. https://doi.org/10.1080/0042098992908

World Bank (2002). Country Assessment Report-Zambia: Upgrading of Low Income Settlements. Africa Technical Unit $1 \& 2$.

http://web.mit.edu/urbanupgrading/upgrading/case-examples/overview-africa/country -assessments/reports/Zambia-report.html\#4\%20Upgrading

World Bank (2009). World Development Report 2009: Reshaping Economic Geography. Washington DC: World Bank.

https://openknowledge.worldbank.org/handle/10986/5991

World Bank (2013). Inclusion Matters: The Foundation for Shared Prosperity. Washington DC: World Bank. https://openknowledge.worldbank.org/handle/10986/16195

Yasini, M. (2007). A Report on the Status of Unplanned Settlements in Lusaka. Lusaka: Lusaka City Council, Research Unit.

Yin, R. (2003). Case Study Research: Design and Methods (3rd ed., Vol. 5, p. 13). Thousand Oaks, CA: Sage Publication. 